Environment Conservation Journal 15(1 \&2) 221-222, 2014

ISSN 0972-3099 (Print) 2278-5124 (Online)

Abstracted and Indexed

\title{
Effect of textile industrial effluents on seed germination of Lentil (Lens esculentum)
}

\author{
Pawan Kr. Bharti ${ }^{1} \bowtie$ and Pawan Kumar ${ }^{2}$
}

Received: 10.01.2013

Revised: 25.02.2013

Accepted: 02.03.2013

\begin{abstract}
Textile industrial effluents are highly polluted in nature and vary in its compositions. In the adjoining agricultural area of textile industries sector, there is immense degradation of crops productivity being contaminated by irrigation through tubewells or directly from the effluent drain or village pond. The present paper deals with the physico-chemical parameters of textile industrial effluents and its impacts on germination and growth performance of Lentil (Masoor) Lens esculentum, (Family: Leguminoceae, Sub-family: Papillionateae). Seeds were found more tolerant against 25\% concentrated effluent.
\end{abstract}

Keywords: Industrial effluents, lens esculentum, seed germination

\section{Introduction}

Developing countries like India, Bangladesh, etc. discharge the effluents to the surface water without any treatment or sometimes little treatment due to technological and economical limitations. Colours affect the nature of water, inhibit sunlight penetration and reduce the photosynthetic action. Some of the dyes cause rapid depletion of dissolved oxygen in aquatic ecosystem affecting aquatic biodiversity adversely. Industrial effluent when discharged into the pond, pollutants may percolate into ground water. When this water is used for irrigation purpose affects our crop health. The textile effluent had consisting high concentration of trace heavy metals and through its accumulation in different trophic levels of ecosystem ultimately cause the health hazards among livestock and human beings.

\section{Material and Methods}

Effluent was collected from common effluents drain of industrial area of Panipat, Haryana and stored in tightly closed plastic container. Four polythene bags were taken for sowing the 100 treated seeds of Lentil (Lens esculentum) with 750 gm soil in Green house condition and irrigated by industrial effluent for three days.

\footnotetext{
Author's Address

${ }^{\mathbf{1}}$ Shriram Institute for Industrial Research, Delhi

${ }^{2}$ J.M. Environet Pvt. Ltd., Gurgaon

E-mail: gurupawanbharti@rediffmail.com
}

25 seeds were treated with absolute effluent, 25 seeds with $50 \%$ concentrated effluent, 25 seeds with $25 \%$ concentrated effluent and rest 25 seeds were treated with distilled water as control performance. Germination of seeds and growth performance were noticed for each poly bags everyday. Physico-chemical characteristics of effluents were analyzed according to APHA (1995), Trivedi and Goel (1984).

\section{Results and Discussion}

The results of the study are given in table 1 and 2 . The appearance of effluent was pinkish red in common effluent drain of textile industries, which might be due to the presence of various dyes. Mean value of effluent $\mathrm{pH}$ was found alkaline (8.2) at $\mathrm{pH}$ scale. Solids, BOD and COD values were very high, due to the presence of chemicals used in various processes. $25 \%(\mathrm{~S} / 4)$ concentration had shown positive performance of seeds germination, radical and hypocotyls growth, almost similar to control condition with distilled water, while $50 \%$ (S/2) concentration showed some negative effects on per cent seed germination and growth of seedlings. Saxena and Kaushik (2005) \& Bharti and Kumar (2012) also reported the similar effects of effluents on seed germination. $100 \%$ absolute effluent (S) was found very unfavorable for seeds germination and growth of seedlings. Highest root 
length of germinated seeds with $100 \%$ Dutta and Boissay (1998) also stated that concentration effluent was found $1.60 \mathrm{~cm}$ on third day, which was the shortest root among all the radicals in any poly bag. 25\% (S/4) concentrated effluent indicated the high growth rate and seed germination among all other concentrations and it was similar to control conditions with distilled water.

theeffluent at low concentrations exhibit greater shoot and root length. Seeds of Lentil (Lens esculentum) were found more tolerant against $25 \%$ concentrated effluent, while against $100 \%$ absolute effluent it was found too week as only 10 seeds were germinated in poly bag consists of total 25 seeds.

Table-1: Characteristics of common effluents of textile industries

\begin{tabular}{|c|c|c|c|c|c|c|c|c|c|c|c|c|}
\hline $\begin{array}{l}\text { Parameter } \\
\text { (Unit) }\end{array}$ & Color & Odor & $\mathbf{p H}$ & $\begin{array}{l}\text { Temp } \\
\left({ }^{\circ} \mathrm{C}\right)\end{array}$ & $\begin{array}{l}\text { TS } \\
\text { (mg/l) }\end{array}$ & $\begin{array}{l}\text { TDS } \\
\text { (mg/l) }\end{array}$ & $\begin{array}{l}\text { TSS } \\
\text { (mg/l) }\end{array}$ & $\begin{array}{l}\text { DO } \\
\text { (mg/l) }\end{array}$ & $\begin{array}{l}\text { BOD } \\
\text { (mg/l) }\end{array}$ & $\begin{array}{l}\text { COD } \\
\text { (mg/l) }\end{array}$ & $\begin{array}{l}\text { Cl } \\
\text { (mg/l) }\end{array}$ & $\begin{array}{l}\text { Alkalinity } \\
\text { (mg/l) }\end{array}$ \\
\hline $\begin{array}{l}\text { Common } \\
\text { Effluent }\end{array}$ & $\begin{array}{l}\text { Pinkish } \\
\text { Red }\end{array}$ & Threshold & $\begin{array}{l}8.2 \\
\pm 0.14\end{array}$ & $\begin{array}{l}22.5 \\
\pm 1.5\end{array}$ & $\begin{array}{l}370.0 \\
\pm 90.0\end{array}$ & $\begin{array}{l}336.3 \\
\pm 81.89\end{array}$ & $\begin{array}{l}33.6 \\
\pm 8.21\end{array}$ & $\begin{array}{l}1.64 \\
\pm 0.21\end{array}$ & $\begin{array}{l}272.5 \\
\pm 42.5\end{array}$ & $\begin{array}{l}791.5 \\
\pm 51.5\end{array}$ & $\begin{array}{l}340.8 \\
\pm 28.4\end{array}$ & $\begin{array}{l}590 \\
\pm 60\end{array}$ \\
\hline
\end{tabular}

Table2: Germination activities of Lentil (Lens esculentum) during experiment.

\begin{tabular}{|c|c|c|c|c|c|}
\hline Effluents & $\begin{array}{l}\text { Exposure } \\
\text { Hour }\end{array}$ & $\begin{array}{l}\text { Number of } \\
\text { seed }\end{array}$ & $\begin{array}{l}\% \\
\text { Germination }\end{array}$ & $\begin{array}{ll}\text { Radical } & \text { (Root) } \\
\text { Length (Cm) }\end{array}$ & $\begin{array}{l}\text { Hypocotyls } \\
\text { (Shoot) Length (Cm) }\end{array}$ \\
\hline \multirow{3}{*}{$100 \%(S)$} & 24 & 25 & 40 & 0.95 & - \\
\hline & 48 & 25 & 48 & 1.55 & - \\
\hline & 72 & 25 & 52 & 1.60 & 1.30 \\
\hline \multirow{3}{*}{$50 \%(\mathrm{~S} / 2)$} & 24 & 25 & 60 & 0.95 & - \\
\hline & 48 & 25 & 68 & 1.60 & - \\
\hline & 72 & 25 & 72 & 1.75 & 1.45 \\
\hline \multirow{3}{*}{$25 \%(\mathrm{~S} / 4)$} & 24 & 25 & 84 & 1.00 & - \\
\hline & 48 & 25 & 88 & 1.75 & - \\
\hline & 72 & 25 & 92 & 1.95 & 1.75 \\
\hline \multirow{3}{*}{$\begin{array}{l}\text { Control } \\
\text { (Distilled water) }\end{array}$} & 24 & 25 & 72 & 0.95 & - \\
\hline & 48 & 25 & 76 & 1.55 & - \\
\hline & 72 & 25 & 80 & 1.75 & 1.50 \\
\hline
\end{tabular}

\section{References}

APHA 1995. Standard method for examination of water and waste water, American Public Health Association, $19^{\text {th }}$ edition, Inc., New York, pp: 1170.

Bharti, P.K. and Kumar, P. 2012. Seed Germination of wheat (Triticum aestivum) and effect of textile industrial effluents on radical and hypocotyls lengths, Environ. Cons .J., 13 (1-2): 39-41.

Dutta, S.K. and Bioissay, C.L. 1998. Effect of paper mill effluents on chlorophyll leaf area and grain number in transplanted rice (Oriza sativa), J. Ind. Poll. Cont., 14 (2):141-145

Saxena, R. and Kaushik, K. 2005. Effect of the effluent of Indian Wood Product (IWP), Izatnagar on seed germination of pigeon pea, Cajanus cajan, J. Ind. Poll. Cont.,21 (10:151-154.

Trivedi, R.K. and Goel, P.K. 1984. Chemical and biological methods for water pollution studies, Environmental Publication, Karad, pp 1-251. 